\title{
PERSEPSI PENGEMBANGAN KARIR DITINJAU DARI KONFLIK PERAN GANDA DAN DUKUNGAN SOSIAL PADA KARYAWAN WANITA DI PT. GULA PUTIH MATARAM LAMPUNG TENGAH
}

\author{
Viranda Rinantri dan Alimatus Sahrah \\ Universitas Mercu Buana Yogyakarta \\ Email: virandarinantri@yahoo.com
}

\begin{abstract}
Abstrak: Persepsi Pengembangan Karir Ditinjau dari Konflik Peran Ganda dan Dukungan Sosial pada Karyawan Wanita di PT. Gula Putih Mataram Lampung Tengah. Penelitian ini bertujuan untuk menguji hubungan antara konflik peran ganda dan dukungan sosial dengan persepsi pengembangan karir pada karyawan wanita. Subyek penelitian adalah karyawan wanita yang bekerja di bagian personalia pada PT. Gula Putih Mataram Lampung Tengah, yang berjumlah 62 orang yang telah bekerja minimal satu tahun. Pengumpulan data menggunakan skala persepsi pengembangan karir, skala konflik peran ganda, dan skala dukungan sosial. Data dianalisis dengan teknik regresi. Hasil penelitian menunjukkan bahwa yang memiliki pengaruh paling besar yaitu dukungan sosial dengan nilai beta = 0,473 sedangkan konflik peran ganda dengan nilai beta $=-0,335$. Konflik peran ganda memberikan pengaruh terhadap persepsi pengembangan karir sebesar 10,4 persen dan dukungan sosial memberikan pengaruh sebesar 23,4 persen terhadap persepsi pengembangan karir, maka dapat disimpulkan koefisien regresi ganda antara konflik peran ganda dan dukungan sosial sebesar 0,581 atau $(\mathrm{p}<0,01)$ dari kedua prediKtor pada persepsi pengembangan karir.
\end{abstract}

Kata kunci: persepsi pengembangan karir, konflik peran ganda dan dukungan sosial

\begin{abstract}
Perception of Career Development Observed from Conflict of Dual Role and Social Support on Female Employees on PT. Gula Putih Mataram Lampung Tengah. The aim of this research was to examine the relation between doable role conflict and social support toward women who work in carrier development perception. The subject of this research was 62 women who work in human resource at PT.Gula Putih Mataram, Central Lampung who had minimum a year experience. Data were collected by using carrier development perception scale, double role conflict scale and social support scale. Here the data was analyzed with double regretion. The result showed that the biggest affed of this analysis were social support with beta value 0,473 , instead of double role conflictbeta value $-0,335$ in short, double role conflict gave $10,4 \%$ affection for carrier development perception and $23,4 \%$ in social support.
\end{abstract}

Keywords: perceptions of carrier development, double role conflict and social support

\section{PENDAHULUAN}

Saat ini banyak wanita yang telah memasuki dunia kerja, bekerja bagi wanita merupakan kesempatan untuk mengaktualisasikan diri. Bekerja memungkinkan wanita mengekspresikan dirinya sendiri dengan cara yang kreatif dan produktif untuk menghasilkan 
sesuatu yang mendatangkan kebanggaan terhadap diri sendiri, terutama jika prestasinya mendapatkan penghargaan dan umpan balik yang positif. Melalui bekerja, wanita berusaha menemukan arti dan identitas dirinya, pencapaian tersebut mendatangkan rasa percaya diri dan kebahagiaan (Mangkuprawira, 2004).

Menurut Bernardin dan Russel (1998) persepsi pengembangan karir merupakan serangkaian proses pengembangan diri karyawan dalam menyeleksi, mengorganisasikan dan menginterpretasikan informasi yang di terima dari organisasi menjadi suatu gambaranyangutuh dalammerencanakan karirnya. Bernadin dan Russel juga menambahkan bahwa komponenkomponen persepsi pengembangan karir, meliputi: Sarana penilaian diri, karyawan memahami kejelasan dalam perecanaan karirnya, Konseling individu (job posting, assessment, presentasi), karyawan mampu mendiskusikan tentang karirnya dengan pihak-pihak yang dapat mengembangkan karirnya, Jasa informasi, karyawan mengetahui dan memahami sistem penempatan kerja serta informasi yang berkaitan dengan pengembangan karirnya. Program awal ketenagakerjaan dalam organisasi, karyawan memahami program sosialisasi awal, Program penilaian, karyawan memahami penilaian karir bagi dirinya, sehingga ia mampu meramalkan kemajuan karirnya, Program pengembangan, karyawan merencanakan pengembangan karirnya.

Menurut Bass (1990) bahwa wanita memiliki kesempatan dan kemampuan yang sama dengan pria dalam hal mengembangkan karir. Namun wanita cenderung menolak ketika mendapatkan penawaran untuk dipromosikan ke jabatan baru, dikarenakan wanita selain memikirkan karir kerja, ia juga harus memikirkan keluarganya. Lebih lanjut Rustam (1993) menambahkan bahwa wanita seringkali menolak peluang pengembangan karir yang ditawarkan kepadanya, hal ini dikarenakan wanita dalam mengembangkan karir tidak diraihnya sendiri, ia juga mempertimbangkan tugasnya sebagai istri, sehingga membuatnya kurang berminat untuk mengembangkan karirnya atau memimpin suatu organisasi kerja.

Tidak jarang wanita harus mengorbankan kemungkinan pengembangan karirnya, jika hal ini mengharuskan ia berpisah dari keluarganya. Tidak sedikit pula wanita yang berpendidikan tinggi atau sudah membangun karirnya terpaksa meninggalkan karirnya karena status pernikahan yang mengharuskan ia berperan penuh sebagai ibu rumah tangga dan pendamping bagi suaminya.

Dari hasil wawancara bersama beberapa karyawan wanita yang bekerja di bagian personalia PT. Gula Putih Mataram Lampung Tengah, pada Hari Senin Tanggal 25 Agustus 2014 terkait persepsi pengembangan karir, dapat dijelaskan bahwa hampir sebagian karyawan wanita yang di wawancarai menjelaskan bahwa mereka merasa tidak dapat mengembangkan karirnya menuju ke karir yang lebih baik, dikarenakan letak geografis atau lokasi perusahaan berada di tengah hutan dan jauh dari pemukiman rumah warga. Hal tersebut di perpara juga dengan kondisi jalanan dari rumah menuju ke perusahaan kurang baik, dan membutuhkan waktu cukup lama untuk menempuh perjalanan dari rumah hingga sampai ke lokasi perusahaan tempat kerja.

Kenyataan kondisi di atas, di akui oleh sebagian karyawan wanita sebagai alasan sehingga mereka kurang memikirkan pengembangan karirnya, dan bagi mereka yang penting bekerja 
sesuai tanggungjawab kerja yang mereka kerjakan saat ini dan bekerja sesuai standar waktu kerja yang berlaku, yakni masuk kerja pukul 08.00 WIB dan pulang kerja pukul 15.30 WIB.

Mereka juga beranggapan bahwa jika jabatan kerja mereka semakin tinggi, itu sama saja akan menambah tugas-tugas dan jam kerja mereka di tempat kerja, dan hal itu dapat mengurangi waktu mereka untuk mengurusi keluarga. Apalagi bagi karyawan wanita yang masih memiliki anak kecil dan masih memerlukan perhatian penuh darinya, tak jarang suami sering melarang jika waktu mereka terlalu banyak dihabiskan di tempat kerja di banding waktu untuk mengurusi keluarga.

Di antara beberapa karyawan wanita yang berhasil di wawancarai ada juga yang menjelaskan bahwa, tidak jelasnya aturan tahapan pengembangan karir di perusahaan, dikarenakan tidak ada penjelasan dan sosialisasi dari pihak perusahaan maupun atasan mengenai tahapan pengembangan karir untuk karyawan, khususnya tahapan pengembangan karir bagi karyawan wanita. Sehingga karyawan wanita cenderung tidak terlalu tertarik untuk mengikuti pelatihan pengembangan kerja yang di adakan oleh perusahaan, yang penting bagi mereka adalah sebisa mungkin bekerja sesuai tanggungjawab yang ada saat ini, dan masih bisa membagi waktu untuk mengurusi keluarga.

Hal di atas menurut Linandar (2009) bahwa meskipun secara formal kebijakan pemerintah dan undang-undang ketenagakerjaan nomor 13 Tahun 2003 pasal 156 telah memberikan kesempatan yang sama luasnya bagi pria dan wanita untuk menuntut ilmu, mengembangkan karir, dan memperoleh perlakuan yang tidak diskriminatif. Namun kenyatannya wanita lebih banyak menemui kendala dari pada pria dalam hal mengembangkan karirnya.

Menyikapi permasalahan pengembangan karir yang ada dilingkungan perusahaan, seharusnya para karyawan wanita menanyakan tentang kejelasan aturan tahapan pengembangan karir yang ada di perusahaan kepada pihak perusahaan atau atasan mereka, agar mereka bisa lebih jelas memahami serta lebih siap untuk menentukan arah pengembangan karir mereka.

Begitu juga dalam hal pembagian waktu antara bekerja dan mengurusi keluarga, seharusnya para karyawan wanita terutama karyawan wanita yang masih memiliki anak kecil, diharapkan mampu mengatur dan membagi waktu antara karir dan mengurusi keluarga agar menghindari munculnya konflik peran antara urusan pekerjaan dan keluarga, sehingga ia akan tetap berkarir dengan baik dan tetap bisa mengurusi keluarganya. Dengan demikian apa yang menjadi kebijakan pemerintah melalui undang-undang ketenagakerjaan nomor 13 Tahun 2003 pasal 156 tentang kesempatan yang sama luasnya bagi pria dan wanita untuk menuntut ilmu, mengembangkan karir, dan memperoleh perlakuan yang tidak diskriminatif bisa terwujud secara optimal.

Menurut Munandar (2001) faktorfaktor yang mempengaruhi persepsi pengembangan karir bagi wanita terdiri dari dua bagian yakni bersifat internal (tergantung pada diri sendiri), yakni: (1) aktualisasi diri, (2) motivasi, (3) konflik peran ganda, (4) rasa bersalah, (5) berani sukses, (6) pendidikan. Sedangkan yang bersifat eksternal (tergantung kondisi keluarga, komunitas, masyarakat, dan budaya), yakni dukungan sosial dan lingkungan kerja pekerjaan.

Dari uraian hasil wawancara dengan beberapa karyawan wanita, 
serta pendapat ahli mengenai faktorfaktor yang memperngaruhi persepsi pengembangan karir karyawan wanita di atas, dapat disimpulkan bahwa terdapat dua faktor yang memperngaruhi persepsi pengembangan karir wanita yang bekerja di bagian personalia PT. Gula Putih Mataram Lampung Tengah, yakni faktor konflik peran ganda dan faktor dukungan sosial.

Menurut Sekaran (1986) konflik peran ganda adalah permasalahan yang di alami oleh ibu rumah tangga, baik sebagai istri atau karyawan dalam memperoleh kehidupan sosial yang lebih baik. Sekaran juga menambahkan bahwa aspek-aspek konflik peran ganda meliputi: (1) pengasuhan anak, (2) bantuan pekerjaan rumah tangga, (3) komunikasi dan interaksi dengan keluarga, (4) waktu untuk keluarga, (5) menentukan prioritas, (6) tekanan karir dan keluarga.

Konflik peran ganda merupakan salah satu masalah yang sering di alami oleh karyawan wanita dalam hal karir, dikarenakan adanya peran ganda antara mengurusi pekerjaan dan keluarga yang berjalan tidak seimbang, dimana individu tidak dapat mengelola tuntutan di tempat kerja dan adanya tuntutan tanggugjawab dalam menjalankan perannya di kehidupan rumah tangganya secara baik, sehingga memunculkan ketidakseimbangan antara urusan pekerjaan dan keluarga.

Uraian di atas di perkuat juga oleh penelitian Munandar (1985) bahwa kesulitan-kesulitan yang dirasakan oleh wanita karir yang sudah menikah yakni waktu di rasa terlalu sempit, wanita karir sering dalam keadaan terburu-buru dan tertekan oleh urusan rumah tangganya sebelum memulai pekerjaan di tempat kerjanya, wanita karir juga akan merasa tidak tenang bekerja apabila anaknya sakit, adanya kesulitan yang timbul akibat orang-orang yang biasa membantu untuk urusan pengasuhan anak dan pekerjaan rumah tangga tiba-tiba harus pergi meninggalkan keluarganya.

Begitu juga dalam hal pengembangan karir, walaupun secara umum organisasi sudah menyediakan tahapan pengembangan karir bagi semua karyawan. Namun umumnya karyawan wanita akan lebih banyak menemui kendala dalam mengembangkan karirnya di banding karyawan pria. Misalnya jika ada pelatihan kerja selama tiga hari di luar kota, dan menuntut ia untuk mengikuti pelatihan tersebut dan harus meninggalkan keluarganya, kondisi ini akan terasa berat jika dijalankan oleh karyawan wanita yang masih memiliki anak kecil dan memerlukan pengasuhan penuh darinya. Hal-hal seperti inilah yang biasanya membuat wanita akan terasa sulit untuk mengikuti proses tahapan pengembangan karir yang ada di dalam organisasi, dikarenakan selain memikirkan karirnya, ia juga harus memilikirkan keluarganya.

Johnson dan Johnson (2000) mendefinisikan dukungan sosial sebagai keberadaan orang lain yang dapat diandalkan untuk di mintai bantuan, dorongan, dan penerimaan apabila individu mengalami kesulitan. Selain keluarga sebagai sumber dukungan dapat juga berupa jaringan sosial, misalnya relasi individu dalam masyarakat, dapat berupa afiliasi kelompok, misalnya individu sebagai anggota tertentu, dan dapat berupa interaksi antara pribadi. Johnson dan Johnson juga menambahkan bahwa bentuk-bentuk dukungan sosial meliputi: perhatian emosi, bantuan instrumental, bantuan informasi, penilaian.

Karir bagi seorang wanita merupakan salah satu pilihan secara sadar 
dan merupakan panggilan hati nurani, yang dapat memberikan dukungan financial secara ekonomi karena dengan penghasilan yang ia terima dapat membantu suaminya untuk memenuhi kebutuhan, keperluan rumah tangga. Disamping itu, karir bisa berarti mempraktekkan, mengembangkan dan memanfaatkan pengetahuan dan wawasan yang ia miliki.

Namun hal tersebut cukup sulit untuk dicapai oleh seorang wanita karir, jika pekerjaan di kantor dirasa banyak dan tidak ada rekan kerja ataupun atasan yang dapat dimintai bantuan ketika ia mengalami kesulitan dalam menyelesaikan pekerjaannya. Sementara di kehidupan rumah tangga juga banyak hal yang harus dikerjakannya guna memenuhi semua keperluan keluarga, sedangkan suami kurang bisa di ajak bekerja sama untuk menyelesaikan tugas-tugas rumah tangga, belum lagi adanya tuntutan dari anak-anak dalam hal pengasuhan.

Sehingga wanita dalam hal mempersepsikan pengembangan karirnya akan lebih banyak memerlukan dukungan atau bantuan dari orang lain. Misalnya adanya dukungan perhatian emosi yang diberikan oleh suami, bahwa suami bersedia bekerjasama untuk mengurusi keperluan rumah tangga. Begitu juga adanya bantuan yang ia peroleh dari rekan kerja dan atasan di tempat kerja ketika ia mengalami kesulitan dalam menyelesaikan pekerjaannya.

Jika dukungan tersebut diperolehnya maka dapat membuatnya bekerja dengan tenang, sehingga dalam mempersepsikan pengembangan karirnya pun bisa berjalan dengan baik, atau sebaliknya jika ia tidak memperoleh dukungan dari suami, rekan kerja dan atasannya, maka ia akan mengalami kesulitan dalam mengembangkan karirnya. Hal ini sejalan dengan pendapat Adams (1996) bahwa dalam karir seorang wanita akan lebih banyak memerlukan dukungan dari orang lain yang bisa dimintai bantuan agar ia lebih mudah menyelesaikan tugas-tugasnya, bantuan tersebut seperti adanya pengertian suami untuk membantunya menyelesaikan tugastugas rumah tangga.

Hal di atas juga sejalan dengan hasil penelitian yang dilakukan oleh Mohr (2000) bahwa kesuksesan wanita dalam karir ditunjang juga dengan adanya dukungan dari suami dan keluarga yang senantiasa memberikan dorongan agar ia terus mengembangkan karirnya, serta adanya dukungan dari atasan dan rekan kerja yang diperolehnya di tempat kerja ketika ia mengalami kesulitan dalam menyelesaikan tugas-tugasnya.

Dari penjelasan di atas, dapat disimpulkan bahwa wanita dalam hal mempersepsikan karirnya, memerlukan dukungan dari suami dan keluarga sebagai bentuk dukungan perhatian emosi agar ia bisa terus mengembangkan karirnya, terutama bagi karyawan wanita yang sudah menikah dan masih mempunyai anak kecil, maka dukungan dan pengertian dari suami akan turut serta menentukan arah bagi dirinya dalam mempersepsikan pengembangan karirnya.

Begitu juga dengan adanya bantuan dan dukungan dari rekan kerja dan atasan ketika ia mengalami kesulitan dalam menyelesaikan tugas-tugasnya, dalam hal ini karyawan wanita cenderung memerlukan bantuan sebagai dorongan agar ia terus bisa menyelesaikan tugasnya dengan baik.

Adapun rumusan masalah dalam penelitian ini sebagai berikut: (1) Apakah ada hubungan antara konflik peran ganda dan dukungan sosial dengan persepsi pengembangan karir pada karyawan 
wanita yang bekerja di bagian personalia PT. Gula Putih Mataram Lampung Tengah; (2) Apakah ada hubungan antara tinggi rendahnya konflik peran ganda, dengan persepsi pengembangan karir pada karyawan wanita yang bekerja di bagian personalia PT. Gula Putih Mataram Lampung Tengah?; (3) Apakah ada hubungan antara tinggi rendahnya dukungan sosial dari keluarga dan lingkungan tempat kerja dengan persepsi pengembangan karir pada karyawan wanita yang bekerja di bagian personalia PT. Gula Putih Mataram Lampung Tengah?

\section{METODE}

Penelitian ini melibatkan tiga variabel sebagai berikut.

Persepsi Pengembangan Karir. Persepsi pengembangan karir merupakan serangkaian proses pengembangan diri karyawan dalam menyeleksi, mengorganisasikan dan menginterpretasikan informasi yang di terima dari organisasi menjadi suatu gambaranyangutuh dalam merencanakan karirnya. Persepsi pengembangan karir wanita akan diungkap dengan skala persepsi pengembangan karir sesuai pendapat Bernadin dan Russel (1998) meliputi: Sarana penilaian diri, konseling individu, jasa informasi, program awal ketenagakerjaan, program penilaiain, program pengembangan.

Konflik Peran Ganda. Konflik peran ganda merupakan masalah yang di hadapi oleh wanita karir yang menjalankan dua peran secara bersamaan, yaitu peran dalam mengurusi karir pekerjaan dan peran dalam mengurusi keperluan keluarga. Konflik peran ganda akan diungkap dengan skala konflik peran ganda sesuai pendapat Sekaran (1986) meliputi: pengasuhan anak, bantuan pekerjaan rumah tangga, komunikasi dan interaksi dengan keluarga, waktu untuk keluarga, penentu prioritas, tekanan karir dan keluarga.

Dukungan Sosial. Dukungan sosial adalah dukungan yang di peroleh karyawan wanita dari atasan, rekan kerja dan keluarga. Dukungan sosial akan diungkap dengan skala dukungan sosial yang dikemukakan oleh Johnson dan Johnson (2000), meliputi perhatian emosi, bantuan instrumental, bantuan informasi, penilaian.

Hasil dari pengujian terhadap validitas dan reliabilitas Skala persepsi pengembangan karir menunjukkan dari 24 item, semua item uji coba memiliki daya tinggi yaitu item-item yang memiliki indeks sama atau lebih dari 0,300. Artinya dalam uji coba skala tersebut tidak ada item yang gugur atau memiliki indeks kurang dari 0,300 . Indeks daya item dalam uji coba penelitian ini, bergerak dari 0,356 sampai dengan 0,566 sebanyak 24 item, dengan reliabilitas alpha 0,869.

Hasil analisis reliabilitas uji coba skala persepsi pengembangan karir menunjukkan dari 24 item, terdapat 21 item yang memiliki indeks daya lebih dari 0,300 . Indeks daya item total correlation dalam uji coba penelitian ini, bergerak dari 0,310 sampai dengan 0,471 , dengan reliabilitas alpha 0,831 .

Hasil dari pengujian terhadap validitas dan reliabilitas skala konflik peran ganda menunjukkan bahwa dari 24 item, terdapat 23 item yang memiliki indeks daya lebih dari 0,300. Indeks daya item dalam uji coba penelitian ini, bergerak dari 0,301 sampai dengan 0,806, dengan reliabilitas alpha 0,889. Sedangkan untuk pengujian validitas dan reliabilitas skala dukungan sosial menghasilkan bahwa dari 24 item yang diujicobakan, memiliki daya indek yang tinggi, yaitu item-item yang memiliki indeks yang sama atau mempunyai nilai lebih dari 0,300. Adapun indeks item 
dalam uji coba penelitian ini bergerak dari 305 sampai dengan 660 sebanyak 24 item, dengan reliabilitas alpha 0,860.

Penelitian ini merupakan penelitian sampel, adapun karakteristik subjek dalam penelitian ini adalah karyawan wanita yang sudah bekerja minimal satu tahun di bagian personalia PT. Gula Putih Mataram Lampung Tengah dan sudah berstatus menikah. Tekhnik analisis data dalam penelitian ini menggunakan tekhnik analisis regresi, yang bertujuan untuk melihat keterkaitan antara variabel penelitian melalui hasil uji hipotesis. Namun sebelum melakukan uji hipotesis, terlebih dahulu dilakukan uji asumsi, uji normalitas sebaran, dan uji linieritas untuk menganalisis hipotesis mengenai hubungan antara persepsi pengembangan karir, konflik peran ganda dan dukungan sosial. Tekhnik ini digunakan untuk mencari korelasi antar variabel bebas yang disebut Predictor dengan variabel tergantung yang disebut Kriterium.

\section{HASIL DAN PEMBAHASAN}

Tabel 1. Nilai Koefisien Korelasi dan Koefisien Determinasi Hipotesis Penelitian

\begin{tabular}{lcccc}
\hline Model & $\mathrm{R}$ & $\begin{array}{c}\mathrm{R} \\
\text { Square }\end{array}$ & $\begin{array}{c}\text { Adjusted } \\
\text { R Square }\end{array}$ & $\begin{array}{c}\text { Std. } \\
\text { Error of } \\
\text { the Es- } \\
\text { timate }\end{array}$ \\
\hline 1 & ,581a & ,338 &, 315 & 6,947 \\
\hline
\end{tabular}

Dari Tabel 1, dapat dijelaskan koefisien determinasi R Square sebesar 0,338. Hasil tersebut memberikan pengertian bahwa variabel dependen yaitu persepsi pengembangan karir dapat dijelaskan oleh variabel independen yang terdiri dari konflik peran ganda dan dukungan sosial dengan nilai sebesar 0,338 sedangkan sisanya 0,571 ditentukan oleh faktor-faktor lainnya, diluar variabel $\mathrm{X}_{1}, \mathrm{X}_{2}$ terhadap variabel $\mathrm{Y}$.

Hasil pengujian secara deskriptif dari 62 responden yang merupakan karyawan wanita yang bekerja di bagian personalia PT.Gula Putih Mataram Lampung Tengah menunjukkan bahwa karyawan wanita yang tidak mengalami konflik peran ganda terhadap persepsi pengembangan karir masuk dalam kategori tinggi. Hal ini ditunjukkan melalui hasil pengisian skala, terdapat lima orang atau 8,1 persen masuk dalam kategori tinggi, dan 50 orang atau sebesar 80,6 persen dengan rerata cumulative percent sebesar 91,9 masuk dalam rentang kategori sendang. Lebih jelasnya dapat dilihat pada Tabel 2 .

Tabel 2 menunjukkan sebanyak 55 karyawan wanita tidak merasa terbebani oleh konflik peran ganda untuk mempersepsikan pengembangan karirnya.Sedangkantujuhorangkaryawan atau 11,3 persen masuk dalam kategori rendah, atau karyawan wanita yang merasa terbebani oleh masalah konflik peran ganda dalam mempersepsikan pengembangan karirnya. Hal ini dipengaruhi oleh aspek ketidakjelasan program awal ketenagakerjaan dan program pengembangan yang ada di dalam organisasi.

Dengan demikian dapat disimpulkan bahwa konflik peran ganda memiliki hubungan negatif dan signifikan terhadap persepsi pengembangan karir pada karyawan wanita yang bekerja di bagian personalia PT. Gula Putih Mataram Lampung Tengah. Artinya semakin tinggi konflik peran ganda yang di rasa oleh para karyawan wanita, maka akan semakin rendah persepsi pengembangan karir, atau sebaliknya jika semakin rendah konflik peran ganda yang di rasa oleh para karyawan wanita, maka akan semakin tinggi persepsi pengembangan karir. 
Tabel 2. Kategorisasi Konflik Peran Ganda Berdasarkan Frekuensi

\begin{tabular}{llcccc}
\hline No & Kategori & Frequency & Percent & Valid Percent & $\begin{array}{c}\text { Cumulative } \\
\text { Percent }\end{array}$ \\
\hline 1 & Rendah & 7 & 11,3 & 11,3 & 11,3 \\
2 & Sedang & 50 & 80,6 & 80,6 & 91,1 \\
3 & Tinggi & 5 & 8,1 & 8,1 & 100,0 \\
\hline & Total & 62 & 100,0 & 100,0 & - \\
\hline
\end{tabular}

Hasil yang diperoleh dari penelitian ini sejalan dengan teori yang dikemukakan oleh Munandar (2001) bahwa konflik peran ganda pada seorang istri dapat berakibat positif jika peran ganda di pandang sebagai hal yang dapat saling melengkapi dalam hal pemenuhan kebutuhan ekonomi keluarga, misalnya adanya pengertian dari suami yang bisa di ajak bekerja sama untuk pengasuhan anak, sehingga dalam menjalankan perannya, wanita karir juga memperoleh dukungan moril dari suaminya untuk terus meningkatkan karirnya.

Berbagai tugas peran yang dijalani olehwanitakarirtelah menjadifaktoryang dapat mempengaruhi karirnya, terutama bagi wanita yang sudah menikah dan mempunyai anak yang harus mendapat pengasuhan. Kenyataannya di satu sisi seorang ibu tetap terus bekerja dan berkarir sementara di sisi lain ia tidak bisa lepas dari perannya sebagai ibu dan istri saat di rumah dengan berbagai macam tugas rumah tangga. Selama ia masih bisa membagi waktu untuk mengurusi karir dan keluarganya, maka masalah konflik peran ganda bisa di hindari, kecuali terjadi ketidakseimbangan antara kedua peran tersebut, maka akan berpotensi pada munculnya konflik peran ganda yang di rasa bisa membani dirinya, baik dalam berkarir maupun dalam urusan kehidupan rumah tangga(Dancer, 1993).

Berdasarkan hasil analisis hipotesis, dapat dijelaskan juga bahwa, ada hubungan positif dan signifikan dari dukungan sosial terhadap persepsi pengembangan karir. Dengan demikian dapat disimpulkan bahwa dukungan sosial memiliki pengaruh yang positif dan signifikan terhadap persepsi pengembangan karir pada karyawan wanita yang bekerja di bagian personalia PT. Gula Putih Mataram Lampung Tengah. Artinya semakin tinggi dukungan sosial yang di peroleh, maka akan semakin tinggi pula persepsi pengembangan karir, sebaliknya semakin rendah dukungan sosial yang di peroleh, maka akan semakin rendah juga persepsi pengembangan karir.

Hasil kategorisasi variabel dukungan sosial menunjukkan bahwa karyawan wanita yang merasa memperoleh dukungan sosial untuk mempersepsikan pengembangan karirnya masuk dalam kategori tinggi. Hal ini ditunjukkan dari hasil pengisian skala yang diperoleh dari 62 responden karyawan wanita, atau sebanyak 11 orang atau sebesar 17,7 persen masuk dalam kategori tinggi, dan 47 orang atau 75,8 persen masuk dalam kategori sedang dengan cumulative percent sebesar 82,3 persen. Sedangkan empat orang atau 6,5 persen masuk dalam kategori rendah.

Sehingga dapat disimpulkan, karyawan wanita yang bekerja di bagian personalia dalam mempersepsikan pengembangan karirnya memperoleh dukungan sosial, adapun dukungan sosial 
Tabel 3. Kategorisasi Dukungan Sosial Berdasarkan Frekuensi

\begin{tabular}{cccccc}
\hline No & Kategori & Frequency & Percent & Valid Percent & $\begin{array}{c}\text { Cumulative } \\
\text { Percent }\end{array}$ \\
\hline 1 & Rendah & 4 & 6,5 & 6,5 & 6,5 \\
2 & Sedang & 47 & 75,8 & 75,8 & 82,3 \\
3 & Tinggi & 11 & 17,7 & 17,7 & 100,0 \\
\hline \multicolumn{2}{r}{ Total } & 62 & 100,0 & 100,0 & - \\
\hline
\end{tabular}

tersebut berasal dari suami, rekan kerja, dan atasan di tempat kerja, lebih jelasnya dapat dilihat pada Tabel 3.

Hasil penelitian di atas, diperkuat juga oleh hasil penelitian yang dilakukan Farner (1980) bahwa wanita yang di dukung oleh mitra kerja (termasuk ayah dan suaminya) akan lebih maju dari pada wanita yang tidak mendapat dukungan. Fakta sehari-hari di sekitar kita banyak terlihat bahwa wanita-wanita karir yang sukses mempunyai suami dan keluarga yang tidak saja mendukung, tetapi juga mendorong karirnya, seringkali para suami itu adalah orang yang juga sukses.

Begitu juga dengan hasil analisis regresi linier berganda yang diperoleh dalam penelitian ini, menunjukkan bahwa variabel konflik peran ganda berhubungan secara negatifdan signifikan terhadap persepsi pengembangan karir dengan koefisien regresi sebesar $-0,322$ dengan nilai probabilitas signifikan 0,002 di bawah nilai signifikan yang ditetapkan sebesar $<0,005$. Sedangkan pada variabel dukungan sosial secara langsung berhubungan positif dan signifikan yakni menghasilkan koefisien regresi sebesar 0,517 dengan probabilitas signifikan 0,000 di bawah nilai signifikan yang ditetapkan yakni $<0,005$.

Hasil tersebut sejalan dengan pendapat Greenhaus dan Beutell (1985) yang menyatakan bahwa konflik peran ganda dari hubungan timbal balik antara domain keluarga dan pekerjaan, dimana pekerjaan yang dirasakan oleh wanita karir bisa dijalankan dengan baik apabila tidak ada intervensi (tekanan yang berarti) dari keluarga, terutama tekanan dari suami. Hal ini membuktikan bahwa konflik peran ganda dapat menyebabkan akibat yang berbeda-beda bagi wanita karir dalam mempersepsikan pengembangan karirnya, seperti halnya hasil hubungan harmonis dan saling pengertian dalam membina rumah tangga, bahwa seorang wanita karir, walaupun sudah menikah masih bisa berkarir jika ia mampu membagi waktu untuk menemani anak-anaknya, dapat menjaga keharmonisan rumah tangga dengan cara membina komunikasi yang baik dengan suami.

Hasil yang di peroleh dari variabel dukungan sosial terhadap persepsi pengembangan karir di pengaruhi oleh adanya bantuan instrumental seperti bantuan langsung berupa barang dan bantuan pelayanan, tingginya dukungan sosial terhadap karyawan wanita dalam mempersepsikan pengembangan karirnya, dikarenakan adanya dukungan atasan seperti memberikan motivasi kerja, adanya dukungan rekan kerja yang siap membantu ketika dibutuhkan bantuan, adanya bantuan suami untuk menyelesaikan tugas-tugas rumah tangga. Keberadaan orang lain yang dapat diandalkan untuk dimintai bantuan, dorongan, dan penerimaan diri individu saat ia mengalami kesulitan. 


\section{SIMPULAN}

Berdasarkan hasil analisis data dan pembahasan terhadap hasil hipotesis mayor, maka dapat disimpulkan bahwa ada hubungan antara konflik peran ganda dan dukungan sosial dengan persepsi pengembangan karir pada karyawan wanita yang bekerja di bagian personalia PT. Gula Putih Mataram Lampung Tengah. sedangkan untuk hasil hipotesis minor dalam penelitian ini menyatakan bahwa: (1) Ada hubungan negatif antara konflik peran ganda dengan persepsi pengembangan karir pada karyawan wanita, yaitu semakin tinggi konflik peran ganda, maka akan semakin rendah persepsi pengembangan karir pada karyawan wanita, dan sebaliknya semakin rendah konflik peran ganda, maka akan semakin tinggi persepsi pengembangan karir pada karaywan wanita. (2) Ada hubungan positif antara dukungan sosial dengan persepsi pengembangan karir pada karyawan wanita, yaitu semakin tinggi dukungan sosial, maka akan semakin tinggi pula persepsi pengembangan karir pada karyawan wanita, dan sebaliknya semakin rendah dukungan sosial, maka akan semakin rendah juga persepsi pengembangan karir pada karyawan wanita.

Berikut beberapa saran berdasarkan hasil penelitian tersebut. Bagi Wanita Karir. Sebagai seorang wanita yang ingin menjalankan karir hendaknya perlu menjaga keseimbangan peran gandanya antara memikirkan pekerjaan dan urusan rumah tangganya, dengan harapan kedua peran tersebut dapat dijalankan dengan baik. Seorang wanita karir juga harus mendapatkan dukungan dari lingkungan sosialnya baik dukungan yang berasal dari keluarga, suami, rekan kerja dan atasan, dengan harapan bahwa dari dukungan tersebut ia akan lebih mampu untuk mengembangkan karirnya. Begitu juga dalam hal pemeliharaan hubungan yang baik dengan lingkungan sekelilingnya, setidaknya akan memberikan dukungan moril dan emosional sebagai bentuk penyemangat kerja bagi wanita karir.

Bagi Peneliti Selanjutnya. Penelitian ini sudah dilakukan secara optimal untuk mengungkap keterkaitan hubungan antara variabel konflik peran ganda dan dukungan sosial dengan persepsi pengembangan karir pada karyawan wanita. Namun idealnya dalam sebuah penelitian, tentu saja masih ada kemungkinan terdapat kelemahan. Kelemahan tersebut adalah subyek dalam penelitian ini hanya diambil dari satu bagian unit kerja yang ada dalam organisasi, sehingga hasil yang di peroleh dari penelitian ini bisa jadi belum mewakili persepsi karyawan wanita secara maksimal dalam mempersepsikan pengembangan karirnya, oleh sebab itu bagi peneliti selanjutnya akan lebih baik jika penelitiannya diberikan kepada karyawan wanita yang bekerja pada beberapa unit bagian yang ada dalam organisasi, dan apabila dapat dilakukan lebih dari satu organisasi, maka hasilnya akan lebih baik dan bisa dijadikan sebagai acuan umum bagi peneliti-peneliti selanjutnya.

\section{DAFTAR PUSTAKA}

Adams, G.A., King, L. A., \& King, D.W. 1996. Relationship of Job and Family Involment, Family Social Support and Work-family Conflict with Job and Life Satisfaction. Journal of Applied Pshychology. Vol. 81, 411-420.

Bass, B.M. 1990. Handbook of leadership Theory: Research and Managerial Application. (3 ed). London: Collier Macmillan Publisher.

Bernardin, H.J., \& Russel J.E.A. 1998. Human Resource Management an 
Experientia. Approach. International Edition. Psychology Series (2ed). New York: McGraw-Hill.

Dancer, L,S. 1993. Spouses Family Work Participations and Its Relation to Wifes Occupational Level. Sex Roles: A Journal of Research. Vol 28, 3-4.

Farner, H.S. 1980. Environemental, Background, and Psychological Variables Related to Optimizing Achievement and Career Motivation for High School Girls. Journal of Vocational Behavior. Vol 17, (1) 58-70

Greenhaus, J.H., \& Beutell, N.J. 1985. Sources of Conflict Between Work and Family Roles. Academic of Management Review, 10,76-88.

Johnson, D.W., \& Johnson, F.P. 2000. Joining Together: Group Theory and
Group Skill. (7.ed). Englewood Chiffs: Prentice-Hall,Inc.

Mangkuprawira, S. 2004. Manajemen SDM Strategik. Jakarta: PT Ghalia Indonesia.

Mohr, G.B. 2000. The changing sifnifice of different stressor, social support and well-being among two-career couple. Journal of Organization Behaviour, 13,339-356.

Munandar, S.C.U. 1985. Emansipasi dan Peran Ganda Wanita Indonesia. Jakarta: Universitas Indonesia (UI-Press).

Munandar, S.C.U. 2001. Wanita Karir: Tantangan dan Peluang. Yogyakarta: Sunan Kalijaga Press.

Sekaran, U. 1986. Dual-Career Families. San Fransisco: Jossey Bass Publishers. 